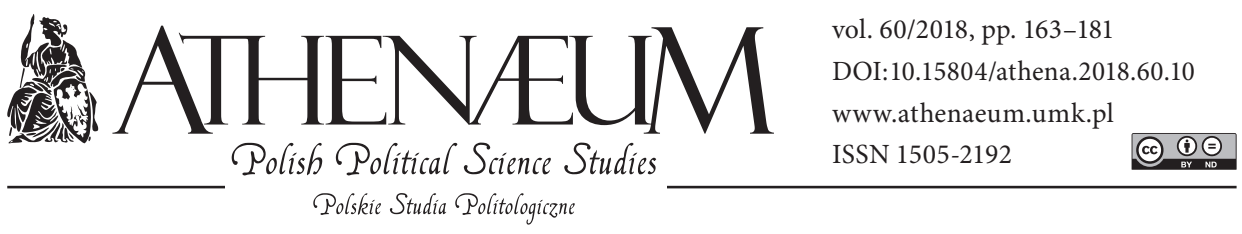

\title{
POLAND'S FOREIGN POLICY TOWARDS THE EUROPEAN UNION 2015-2017: A HARD COOPERATION MODEL OR A COLLISION COURSE?
}

\author{
POLITYKA ZAGRANICZNA POLSKI \\ WOBEC UNII EUROPEJSKIEJ 2015-2017. \\ MODEL TWARDEJ WSPÓŁPRACY CZY KURS KOLIZYJNY?
}

Rafał Willa*๑, Radosław Potorski**๑

\begin{abstract}
- ABSTRACT
After 1989, Poland's foreign policy initially prioritized aiming for membership in the North Atlantic Treaty Organization and the European Union and, upon achieving this goal, the focus shifted to strengthening the bonds with these organizations. This very image was not disturbed even by a short period of time (2005-2007), during which a coalition of the Euroskeptics and the extreme Right ruled the country. However, some symptoms were noticeable back then, regarding a certain change in the manner of thinking about the role of the foreign policy within the framework of state policies or about the model of the unification of Europe. After 8 more years of Poland's existence within the main trend of European integration
\end{abstract}

Po 1989 roku priorytetem Polski w polityce zagranicznej było najpierw dążenie do uzyskania członkostwa, a następnie zacieśnianie więzi łączących ją z Sojuszem Północnoatlantyckim i z Unią Europejską. Tego obrazu nie zmącił nawet krótki okres (2005-2007) sprawowania władzy w kraju przez koalicję eurosceptyków i skrajnej prawicy. Dało się już jednak wówczas zauważyć inny sposób myślenia czy to o roli polityki zagranicznej w ramach polityk państwowych, czy także o modelu jednoczenia Europy. Po kolejnych 8 latach funkcjonowania Polski w głównym nurcie procesów integracji europejskiej na krajowej scenie politycznej nastąpił gwałtowny zwrot w prawo i tym samym przejęcie

* Nicolaus Copernicus University in Toruń, Faculty of Political Sciences and International Studies.

** Nicolaus Copernicus University in Toruń, Faculty of Political Sciences and International Studies. 
processes, a rapid shift to the right occurred on the domestic political scene and in consequence the Law and Justice party achieved full and selfcontained authority. Since that very moment, we have been observing a Warsaw-Brussels conflict that seems to be escalating with almost every passing day. What initiated the conflict? What matters does it concern? What is the possible course of events? In this article, we shall attempt at providing an answer to these, as well as other questions.

Keywords: Poland, European Union, foreign policy pełnej i samodzielnej władzy przez partię Prawo i Sprawiedliwość. Od tego czasu obserwujemy, nasilający się niemal z każdym dniem, spór na linii Warszawa-Bruksela. Od czego się on zaczął? Jakich kwestii dotyczy? Jakie są możliwe scenariusze rozwoju wydarzeń? Spróbujemy na te i inne pytania odpowiedzieć w niniejszym artykule.

Słowa kluczowe: Polska, Unia Europejska, polityka zagraniczna

In recent years, the project under the name "the European Union" (EU) has been going through difficulties. First, there was the economic crisis, still very noticeable in Greece; then came the refugee crisis; finally the citizens grew tired of the left-wing liberal elites and many European societies started shifting to the Right. All these factors contributed to the rise of euroskeptical trends on the Continent. As a result of the wave of critics of the then-current model of the united Europe, in the autumn of 2015 the right-wing party Law and Justice (pol. Prawo i Sprawiedliwość, further abbreviated as "PiS") managed to win the election. Since that moment, it was certain that the country's foreign policy, especially towards the EU, would undergo a significant transformation. There would have been nothing special about that, if it was not for the fact that due to that policy, current relations between Warsaw and Brussels have turned from very good to reserved, at best. The article hereby is an attempt to answer the question, whether this situation is a result of Poland's adopting a model of hard cooperation, which would ultimately lead to concrete success, or perhaps it is a symptom of assuming a certain collision course with Union partners? And also, if it is the latter, what would be the roots for such actions?

For this very reason, the authors shall analyze the main planes of Poland's political activity as far as creating political decisions within the framework of the European Union is concerned. The results of this cognitive process shall then be utilized as the foundation for establishing conclusions that may provide an answer to the aforementioned question. 


\section{MAIN AREAS OF CONFLICTS IN RELATIONS BETWEEN WARSAW AND EUROPEAN INSTITUTIONS AFTER 2015}

\subsection{The Dispute About the Rule of Law in Poland}

Since the dawn of the European project, the main idea behind it was that it should be founded on common, yet non-formalized, values and common trust. This model was not met with any substantial dispute, as the first members of European Communities operated in similar, liberal-democratic political systems and within a free market economy. However, in the effect of progressing integrative processes and their success, further countries (such as Ireland, Greece, Spain, or Portugal) started requesting access, yet their level of social-economic development was not on par with the Community average. Later, they were followed by countries from the former Eastern Bloc. Especially they were quite a challenge for Europe, as for many years they operated within an absolutely different political, economic, and social reality.

Seeking to attract these countries and positively influence the reforms they have undertaken, during the European Council summit the so called Copenhagen criteria were accepted. There was talk of economic factors, as well as the need to prepare the EU itself for the enlargement (European Council, 1993, p. 14). Nevertheless, the political requirements for candidates mentioned then were crucial - they included the existence of stable institutions guaranteeing democracy and the rule of law, respecting human rights and civil liberties, as well as protection of all minorities. Later on, these criteria were also reflected in the Treaty of Amsterdam, which amended the Treaty on European Union (Art. 1 p. 8). Poland's signing and ratifying the Treaty of Accession, the Charter of Fundamental Rights, and the Treaty of Lisbon, amending the Treaty on European Union, was synonymous to confirming being aware of such requirements, their acceptance, and agreeing with them.

Thus, it ought to be obvious that Poland and other EU member countries take cognizance of and accept the regulations concerning the manner of establishing and executing the Community law, controlling it, and verifying its accordance with domestic law. Nevertheless, in order to assure that no Union country shall attempt to question the rules and values arising from the acquis communautaire, certain norms, aiming to preserve them, were included in the Lisbon version of the Treaty on European Union (TEU). Especially interesting in this regard is Art. 17 of the TEU, stating that "The Commission [...] shall ensure the application 
of the Treaties, and of measures adopted by the institutions pursuant to them. It shall oversee the application of Union law under the control of the Court of Justice of the European Union", and Art. $7 \mathrm{sec} .1$ of the TEU, where it is indicated that "On a reasoned proposal by [...] the European Commission, the Council [...] may determine that there is a clear risk of a serious breach by a Member State of the values referred to in Article 2". Bearing in mind merely these two articles, it ought to be noted that European Union institutions not only have the right, but also the obligation to watch over the compliance with general democratic values in the member countries, thus claims that European institutions do not have legal grounds in this respect at their disposal shall be deemed absolutely unfounded.

Since recent times Poland has been presented as an example of a successful transformation in terms of the political system: from an authoritarian state, towards democracy; and in terms of economy: from a centrally planned, to market economy; as well as in terms of successful assimilation to the EU's integration structures. Therefore, it was the more surprising that it was Poland that was to be targeted by the European Commission with procedures regarding the analysis and consolidation of the rule of law, which were established a few years earlier.

Let us begin with a few words of introduction. Before the October 2015 parliamentary elections, the Sejm of the previous (i.e., the 7th) term chose 5 persons that were to be sworn by the President of the Republic of Poland as judges of the Constitutional Tribunal (CT). 3 of them were chosen for positions vacated during the previous term of the Sejm. The remaining 2 were supposed to replace the judges, whose term was to elapse during the next term of the Sejm (starting on $12^{\text {th }}$ November 2015), which caused serious doubts of legal nature (Helsińska Fundacja Praw Człowieka, 2016). Then, on 25 th November 2015 the Sejm in the new composition (of the $8^{\text {th }}$ term) passed a resolution canceling the appointment of all the 5 persons appointed by the Sejm of the previous term and on the $2^{\text {nd }}$ December appointed 5 new judges ${ }^{1}$. In this case there were also doubts of legal nature. Due to this fact the applications were submitted to the CT in order for it to take a stand concerning decisions issued by the Sejm with regard to the appointment of judges, both of the previous and the current term. As a result, the Tribunal passed 2 judgments on the $3^{\text {rd }}$ and $9^{\text {th }}$ December 2015.

1 On 19th November 2015, the Sejm revised the Constitutional Tribunal Act, allowing for stating the invalidity of the appointment of judges during the previous term of the Sejm and for appointing of 5 completely new judges. 
In a judgment from $3^{\text {rd }}$ December (K-34/15), the CT decided that the Sejm from the previous term had the right to appoint 3 persons replacing the judges, whose term elapsed on $6^{\text {th }}$ November 2015. At the same time, the Constitutional Tribunal explained that the Sejm in previous composition did not have the right to appoint 2 judges as a replacement for the ones whose term elapsed in December, i.e., during the term of the new Sejm (Constitutional Tribunal Judgement, $\mathrm{K}-34 / 15)$. Only the Sejm of the next term had the right to do so ${ }^{2}$. However, in a judgment from $9^{\text {th }}$ December (K-35/15), the Tribunal deemed as unconstitutional the legal basis, indicated by the Sejm of the new (8th) term, allowing for canceling the appointment of certain persons as CT judges (Constitutional Tribunal Judgement, K-35/15), thus also the 3 judges already appointed by the Sejm of the previous term. Thus the CT judgments introduced a legal order, in which the appointment of 3 judges from the previous ( 7 th) term and 2 from the new (8th) was deemed as constitutional.

In spite of these judgments, the 3 judges appointed by the Sejm of the previous term did not take their post in the Constitutional Tribunal, as the President of the Republic of Poland did not receive their oath. He did however receive oath from all 5 judges appointed by the Sejm of the new term ${ }^{3}$. Complementing the image of the legal condition, being the basis for the dispute subject to the hereby analysis, was the passing by the Sejm on $22^{\text {nd }}$ December 2015 of an act amending the Constitutional Tribunal Act (Journal of Laws 2015.2217). Among other things, it introduced the obligation of reaching qualified majority $\left(2 /{ }_{3}\right.$ of votes) in the presence of all judges, and not standard majority, as it used to be up to this point; the requirement of investigating cases in the sequence of their submission; possibility of submitting a motion for disciplinary action against a CT judge by the Minister of Justice or the President; and the possibility for the Sejm to make the final decision about the dismission of a judge, as requested by the CT.

As indicated by the European Commission (EC) itself, it started to focus its attention on the matter at hand as soon as in November 2015. Then, on $23^{\text {rd }}$ of December 2015, it submitted to the Polish authorities a written request in order for them to explain the doubts that have arisen. It emphasized objections

2 The judgment emphasized the obligation of the President of the Republic of Poland to immediately accept the oath of a Tribunal judge appointed by the Sejm.

3 The 3 judges who claimed the position of the three appointed by the previous Parliament were commonly referred to as "the duplicate judges". 
as far as legitimacy of the appointment of the CT judges was concerned, as well as the consequences for CT's correct functioning. Also, close cooperation with the Venice Commission was recommended in order to clarify the situation. Interestingly, an application with a request for an opinion was submitted to this institution by the Polish government on that very day (Commission Recommendation, 27.07.2016, \$9-11).

Until March 2016, there were no legal condition changes, however an exchange of letters was initiated between the Union and the Polish authorities, aiming for clarification and specification of standpoints of parties involved. The EC, among other issues, raised doubts as for the acts passed on $30^{\text {th }}$ December 2015 on the public mass media and civil service, as well as latter acts on the prosecution law. The EC decided that current circumstances were causing the need to investigate the Polish case in terms of the framework of the rule of law from 2014. Polish authorities argued that the appointment of the CT judges was legitimate and the act reforming the Constitutional Tribunal was introducing corrective measures and remained in accordance with the constitution. With regard to this, the important event that introduced a significant change was the judgment passed by the CT on $9^{\text {th }}$ March 2016 concerning the act from $22^{\text {nd }}$ December 2015, in which the act was deemed unconstitutional (Commission Recommendation, 27.07.2016, \$ 12-19). Moreover, 2 days later, the Venice Commission adopted its opinion on that act, in which it criticized the proposed changes and appealed for allowing the 3 judges appointed by the Sejm of the $7^{\text {th }}$ term to pass judgments (Venice Commission, 833/2015).

After these events, there was another period of intense letter exchange between the EC and the Polish government, in which both parties were "entrenching themselves" as far as their standpoints were concerned ${ }^{4}$. Also, many meetings on various levels took place $^{5}$. The only effect was the preparation by the Sejm

4 The European Parliament (EP) also engaged in the analysis of the legal condition of Poland. On 19th January 2016, a debate took place in the EP, dedicated to the situation in this country. Then, on 13th April 2016, the EP adopted a resolution regarding it, in which it demanded from the Polish government to immediately start observing, publishing and fully executing the CT judgments from 9th March 2016 and the former from 3rd and 9th December 2015. It also demanded full implementation of the recommendations presented by the Venice Commission (European Parliament, 2016). On 15th November 2017, the EP adopted another resolution concerning the situation in Poland, in which it expressed increasing concern with the direction of changes implemented in the country (European Parliament, 2017).

5 Very important with regard to this matter seem to be the ones with participation of EC Vice-President, Frans Timmermans, on 31st March 2016 in Warsaw, among others with the Prime Minister, 
of the Republic of Poland of yet another act on the Constitutional Tribunal that was supposed to eliminate the errors in previous changes (Journal of Laws 2016.1157). The EC did not share that assessment and decided that it was time to submit its position as a formal opinion sent to Polish authorities, which was adopted on $1^{\text {st }}$ June 2016 and then updated in another one, dated $27^{\text {th }}$ July ${ }^{6}$. In the aforementioned document the Commission emphasized that it noticed a system related threat to the rule of law and with regard to this matter, it recommended to the Polish authorities taking the following actions:

a) full execution of CT judgments from $3^{\text {rd }}$ and $9^{\text {th }}$ of December 2015;

b) publishing and full execution of the CT judgment from $9^{\text {th }}$ March 2016 and guaranteeing of automatic publishing of future judgments;

c) guaranteeing accordance of all amendments of the Constitutional Tribunal Act with CT judgments, including the ones from $3^{\text {rd }}$ and $9^{\text {th }}$ December 2015 and $9^{\text {th }}$ March 2016, as well as full inclusion of the opinion of the Venice Commission (Commission Recommendation, 27.07.2016, § 74).

However, the situation did not improve. At the end of the year, further acts changing the Tribunal's manner of functioning were passed ${ }^{7}$. Especially important in this regard were the regulations for the mode of appointing the new President of the CT. As a particular threat to the rule of law, the EC recognized admitting the so called "duplicate judges" to the procedure of appointing the President of the $\mathrm{CT}^{8}$. In connection to this fact, on $21^{\text {st }}$ December 2016, the EC issued further (complimentary) recommendations, in which it demanded that the Polish government would have resolved this problem within the period of 2 months. That, however, did not happen - the Polish government disagreed with all the points of the recommendation and did not announce any new actions

Chief of the Ministry of Foreign Affairs, the Minister of Justice, and the President and Vice-President of the Constitutional Tribunal, as well as the one dated 24th May 2016, among others with the Prime Minister, the President of the Constitutional Tribunal and the Polish Ombudsman. On the same day, there was also a meeting with members of the opposition party in the Sejm. Then, on 26th May 2016, Timmermans met in Brussels with the Deputy Prime Minister of the Republic of Poland (Commission Recommendation, 27.07.2016, \$22, 25, and 28).

6 The reason for issuing another opinion was passing by the Sejm of the aforementioned act on the CT from the 22nd of July, which at the moment of issuing the opinion from the 1st of June was only a project.

7 In precise terms, these were: the act of 30th November 2016 on the status of the Constitutional Tribunal judges, the act of 30th November 2016 on the organization and proceedings in the Constitutional Tribunal, the act of 13th December 2016 - regulations introducing the act on the organization and proceedings in the Constitutional Tribunal.

8 Naturally, the EC had many more doubts (Commission Recommendation, 21.12.2016). 
with the aim of eliminating the Commission's objections (Commission Recommendation, 27.07.2017, \$8).

Another episode of the ongoing dispute began in July 2017. It was the time of proceeding and adopting by the Parliament of a set of acts changing the manner of functioning of the courts of common law in Poland. These events caused a vivid debate and social protests. Ultimately, the act on the functioning of the courts of common law was signed by the President and came into force, however he vetoed the remaining 2 (i.e., the ones concerning the Supreme Court and the National Council of the Judiciary) ${ }^{9}$. Thus, the EC decided to issue further recommendations for Poland due to the endangerment of the rule of law. They were issued on $26^{\text {th }}$ July 2017, with the Commission repeating previous objections and criticizing the changes proposed in the (at that time) planned acts ${ }^{10}$. It also indicated that adopting new acts in the same form as the vetoed ones or repeating the mechanisms causing the most objections will lead to immediate submission of an application for initiating the procedure from Art. 7 of the TEU (Commission Recommendation, 27.07.2016, §58).

The dispute concerning respecting the rule of law between the Commission and the Polish government is continued. Both parties maintain their standpoints. Interestingly, so far the EC's position corresponded with the opinion of the majority of Polish legal figures of authority and legal profession associations, who assessed that the domestic central public authorities violated the regulations, including the constitution ${ }^{11}$. Commission's opinion also coincides with opinions of many international bodies, such as the aforementioned Venice Commission.

9 The President submitted his own act drafts in this respect. The new acts were signed on 20th December 2017.

10 The EC's remarks concerned aborting the term of the members of the Supreme Court and the possibility of influencing the initiation and course of disciplinary proceedings towards SC judges by the Minister of Justice (Commission Recommendation, 27.07.2016, $\$ 35-42$ and 53d). At this point, it is worth to note that during the time of proceeding the presidential act drafts concerning the National Council of the Judiciary and the Supreme Court, the Polish government did not agree to a visit of the Venice Commission experts, who could have had a closer look at the proposed solutions and asked for explanations from representatives of the parties engaged in the dispute (PiS boi sie Komisji Weneckiej..., 2017). Nevertheless, on 8th December 2017, the Venice Commission adopted two more opinions concerning the acts on the system of the courts of common law and the prosecution, which were already in force at the time, and the presidential act drafts concerning the National Council of the Judiciary and the Supreme Court. Both were very critical for Poland (Venice Commission, 904/2017; 892/2017).

11 Including the General Assembly of Judges of the Supreme Court, the National Council of Legal Advisers, the National Bar Council, the Polish Ombudsman, many faculties of law and constitutional 
Nevertheless, the Polish authorities clearly emphasize that there were no violations of the rule of law and that the Commission's actions are undertaken with no substantiation on the basis of any treaty (Ministry of Foreign Affairs Press Office, 2016).

Thus, without arbitrating the contents and future of the acts drafted by the President concerning the Supreme Court and the National Council of the Judiciary (currently in the works), it seems very likely that the dispute shall continue. Therefore, it ought to be expected that the Union shall commence with the proceeding stage, as directly expressed in Art. 7 of the TEU. In this regard, it is even possible that Poland might be taken away the right to vote in the EU Council, which could not be considered as an instance of violation of the treaties.

Directing the dispute towards this specific procedure shall indicate that the matter would be transferred to political grounds. In this respect, statement of guilt, i.e., violation of the rule of law, seems rather unlikely, as it would require unanimity. Yet, after the events concerning voting in order to extend the term of the President of the European Council, it cannot be deemed absolutely impossible. However, if under the assumption that Poland could count on a veto from at least one of the remaining EU countries in case of a charge with violating the rule of law, it indeed might lead to an impression that the ongoing dispute would not have any negative repercussions for the country. Nonetheless, an intricate analysis of the functioning of the EU's political system and the processes for establishing public policies suggests that such a statement be made with utmost caution. One might perceive certain consequences leaving their mark on levels more distant from the aforementioned Art. 7 of the TEU.

As a starting point, it should to be noted, that even if countries willing to recognize Poland's guilt with regard to Art. 7 of the TEU lose the voting, it ought to be considered that this type of dispute does not seem to be an ordinary conflict within the current political strategy. In this case, the matter it concerns seems to have a serious impact on the development of future relations between the parties involved. For it will be difficult for Union partners (authorities of these countries) to justify in front of their electorate the cooperation with Poland, if before, during voting (even if it was lost), they indicated that they had recognized the situation in Poland as a case of violating the rule of law. All of the above may seriously influence our coalition abilities in terms of future Union initiatives.

law professors, and a huge number of NGOs dealing with the matter of the respect for the legal order (Amnesty International et al., 2017). 
These would be additional consequences, of political nature, resulting from the initiation of the procedure based on Art. 7 of the TEU. Apart from this fact, a question needs to be raised about how non-public entities, among others, from the business sector, would perceive the fact that their government would officially vote for supporting the statement that Poland violated the rule of law in terms of judiciary independence, as in case of a possible dispute on Polish territory it is the court that is supposed to protect their rights and reasons. Casting such a vote might be considered a certain kind of vote of no-confidence for many nonpublic entities, and a formal warning from their authorities as far as engaging in any activities in Poland is concerned ${ }^{12}$. Therefore, all of the above needs to be considered as negative consequences for the image of the country, the effects of which seem to be severe and long-lasting.

In addition, it would be a mistake to assume that Union institutions may evaluate and apply certain types of penalties on member countries only on the basis of the procedure resulting from Art. 7 of the TEU. The EC has other tools at its disposal, granting it significant rights towards the participants of the integration. According to the procedure from Art. 258 of the Treaty on the Functioning of the European Union (TFEU), it can judge whether domestic regulations introduced by member countries are in accordance to the Union law. And if it then recognizes that there was a case of a violation of the EU's regulations, it can bring it before the Court of Justice. The Court of Justice in turn may give a judgment recognizing the specific domestic regulations as violating the EU law and require changing them. If the country does not follow this ruling, it would risk another trial on not executing the judgment of the Court of Justice, which threatens major financial penalties in case it is lost (Półtorak, 2005).

Obviously, at this point it would be correct to bring about an objection that it is not possible to apply the procedure on the basis of Art. 258 of the TFEU to a violation of Union values included in Art. 2 of the TEU. Firstly, for protecting of these, a separate, already mentioned procedure from Art. 7 of the TEU is foreseen. Secondly, the subject of the procedure from Art. 7 of the TEU is "a serious and ongoing violation of values". It is a collective category, which can include many factors influencing the functioning of a certain political system. Nevertheless, it

12 Apart from that, the voting in the EU Council on the judgment of guilt is in fact unanimous. However, the voting preceding it, on the existence of a serious risk of violating the rule of law in the EU Council, requires a majority of $4 / 5$. It ought to be expected that with only one country declaring support for Poland in this matter, achieving this majority is not excluded. 
needs to be noted that "a serious and ongoing violation of values" may concern certain political decisions, but may also be included, partly, in a series of domestic acts adopted, that are composed of specific regulations. Each of these, individually, may be subject to a separate evaluation of the EC within the procedure from Art. 258 of the TFEU, i.e., with regard to an implication, that they are not in accordance with certain EU regulations. The Commission shall thus be able to take actions regarding specific regulations introduced in the legal system of an EU member. All member countries agreed to such a control measure and the EC has full treaty substantiation with this regard ${ }^{13}$.

Thus, it is conceivable that the escalation of conflict with regard to respecting the rule of law in Poland may result in a series of specific disputes concerning separate regulations introduced by Polish authorities. The conflict would then become fragmented and in effect we would witness its gradual transfer to the plane of a separate procedure. What is important in this regard, the EC has full competence, directly recorded in the treaty, to demand explanations from a member country. Moreover, in this procedure, the ultimate entity arbitrating about possible guilt would not be a one of political nature (i.e., the European Council), but the Court of Justice, which represents interests of the Union as an organization. The Court of Justice reached its position thanks to interpreting treaty regulations and quite often arbitrating against country interests, giving priority to efficient functioning of the whole EU system. In this case, expressing political support to each other by certain countries would only have symbolic meaning.

\subsection{The matter of the Białowieża Forest}

It would not be very revealing to state that the European Union attaches a lot of importance to the issue of the environment in its broad sense. To this point, it adopts more and more demanding legal regulations and financially supports, within the limits of its abilities, the entities that need it the most (companies, regions, countries). Poland, due to its geographical scale, size of investment needs,

13 We already experienced a sample of such activity when the EC, in its opinion from July 2017, reproved Poland about certain records in the act on common courts being discordant with the EU law. Moreover, the Commission turned its specific claims into formal procedures, transferring, with accordance to Art. 258 of the TFEU, their comments from the plane of reprimand procedure to the plane of the procedure for violating Union laws. 
or differentiation in flora and fauna, is one of the biggest beneficiaries in this regard.

In the common opinion, one of the most valuable protected areas in Poland is the Białowieża National Park, with the last so called primeval forest in Europe. The information that spruce trees growing in this area were infected by pests to a scale unprecedented for centuries caused vivid interest and concern. The crucial point here is that the Ministry of Environment along with the Directorate of National Forests proposed a remedy for this situation by... intense logging of trees (from 63.5k sqm to $188 \mathrm{k} \mathrm{sqm}$ ), also in key areas of the Park. This decision met with an outrage of many experts as well as a stern reaction from many ecological organizations, which indicated that the proposed cure is worse than a disease, and that the whole matter does not revolve around fighting pests, but is more about selling wood in order to acquire funds for new social programs introduced by the government. Ultimately, the dispute between the authorities and the ecological organizations attracted attention from none other than the European Commission. Having analyzed the materials, on $20^{\text {th }}$ July 2017, it submitted a complaint against Poland (Case C-441/17) before the Court of Justice, referring to a violation of regulations concerning the birds and habitat directives. In another act, submitted in the secretary's office of the Court while awaiting the decision of the Court of Justice, the EC requested applying temporary measures leading to command Poland to stop any forestry activities in this area, with the exclusion of situations threatening the public safety. By the decision of its VicePresident dated $27^{\text {th }}$ July 2017, the Court of Justice complied with this request and the whole issue was subject to an expedited procedure due to the risk of irreversible damage. Also, Poland's application to establish financial collateral of 757 million euro, in case of damage resulting from the implementation of temporary measures, was rejected (Decision of the Vice-President..., 2017).

The matter might have indeed been considered closed at that moment and we could have patiently awaited the final judgment from the Court of Justice, if only Polish authorities had followed this decision. According to ecological organizations, experts, journalists, and opposition politicians, the intensive logging in the Białowieża Forest was not stopped. The ecologists protested on the spot to no effect - they were removed from the logging areas by force, and then passed over to the police; some of them were brought before the court. Even though Polish authorities still firmly emphasized that there were no activities in the Forest that might be deemed discordant with the decision of the Court of Justice, voices of outrage and concern again reached the European Commission. On $17^{\text {th }}$ 
October 2017, it sustained the motion for punishing Poland for the activities in the Białowieża Forest and commanded to stop all work in that area yet again. The Court of Justice also related to these reports, reminding about the previous decision and informing that in case a violation of the logging prohibition is confirmed, Poland shall be punished with a penalty of at least 100k euro per day (Court of Justice..., 2017). Only then gradual retreat of heavy machinery from the territory of the Forest was observed... Everything seems to be pointing to the fact that it was for the very first time in history of European integration that we witnessed a member country not following a decision of the Court of Justice. If the EC proves this during the case, the consequences for Poland might be difficult to predict, but certainly very severe.

\section{OTHER AREAS OF DISPUTE}

In the light of the problem assumed within the hereby analysis, it would be difficult to leave out the fact that Poland does not demonstrate any interest in engaging with certain Community initiatives that might be qualified as aiming to extend the solidarity between members of the integration. In this aspect it is enough to mention issues such as the refugee relocation program, or defence (Balcer et al., 2017, pp. 21-31). With regard to the first matter, the Polish government did not fulfill the obligations incurred by the previous Parliament (i.e., reception of around $7 \mathrm{k}$ previously controlled persons), arguing that this decision is motivated by the matter of safety of Polish citizens. Moreover, it indicates that receiving refugees is not the proper manner of action, and emphasis ought to be laid on strengthening the protection of EU's exterior boundaries and development aid for the countries that need it the most. Despite reprimands, Poland still refuses to participate in the relocation of refugees and has not yet received a single person. As a result of the above, on $7^{\text {th }}$ December 2017, the European Commission decided that Poland violated the European law and the rule of solidarity, and submitted a petition to the Court of Justice (European Commission, 2017).

With regard to the matter of EU's defence in its broad sense, concerns reappeared in Poland that any supranational European defence structures shall be significant competition to the NATO, which Warsaw treats as key to its safety. Thus PiS abandoned the attempts, as taken by its predecessors, of promoting a Union debate concerning the Common Security and Defence Policy. Moreover, 
Poland engaged in activities that may be perceived as an indication of disregarding European military partners. A significant exemplification in this aspect might be the decision (and the manner of its communication) about canceling the contract concerning the purchase of French military helicopters (Caracals) and further purchase, within a non-tender procedure, of American, much more deficient equivalents, only for the Polish Special Forces and not for all kinds of armed forces, as planned before. Moreover, Poland also withdrew from the concept of joint action of purchase of tanker aircraft, under the auspices of the European Defence Agency, and resigned from the efforts to achieve the status of a Framework Nation within the Eurocorps ${ }^{14}$. All these gestures and decisions must have been received negatively by the Western Europe allies and Warsaw got to know its unfavorable side yet again.

It is difficult not to notice that the Polish authorities are not fond of the current structure of the European project. In any case, the discussion about the directions of reforming the EU has so far been continued for years and it is absolutely natural. Unfortunately, the position of the Republic of Poland does not contribute much to the debate about Europe, and can generally be summarized by one statement - instead of moving forward towards deeper integration (federalization), it is all about coming back to the roots, towards the Union of equal countries (renationalization). There still are no details or specifics and from vague statements of the politicians of the ruling party only as much may be inferred that the changes proposed would result in a decision making paralysis of the organization ${ }^{15}$.

On $6^{\text {th }}$ March 2017, Versailles was a place of meeting for leaders of Germany, France, Spain, and Italy; Poland was not invited... In their conclusions the parties decided that certain EU member countries, which have the political will to do so, ought to be allowed more profound integration in detailed matters, without the necessity of considering other countries' opinions. It was therefore the first time that the possibility of shifting towards the so called "multi-speed Union" was formulated. The concept itself is nothing new, as the mechanism has been utilized for quite a while (e.g., the eurozone, Schengen, defence), yet in Poland these words were met with firm disagreement, for according to Warsaw, it would cause

14 There was a serious risk that Poland should decide to opt out of the project of Permanent Structured Cooperation (PESCO) in the area of defence. Yet so far, Warsaw gave notice of the will to participate.

15 This concerns a broader application of the unanimity rule, restricting the competence of the EC, strengthening the role of national parliaments, establishing a catalog of indefeasible competences of countries, or the necessity to establish new treaties. 
a risk of weakening the European Union and perhaps even its disruption. Yet, it is difficult to find proof indicating that Poland's objection in this regard should lead to ceasing the activities on implementing the aforementioned solutions.

A certain kind of response on the part of current Polish authorities to the dominant role of France and Germany and their decisive influence on the mode and direction of debates on integration might be the concept of establishing smaller, local alliances, in which Poland would play a vital role. This would include the idea of creating a strong coalition of countries from Central and Eastern Europe (the Visegrad Group) or the broader concept of the Three Seas Initiative (countries extending between the Baltic Sea, the Adriatic Sea, and the Black Sea). These would serve as a sort of a counterbalance allowing for a chance to rephrase the narrative of Union processes. If they were to succeed, these initiatives ought to be considered as Poland's vital input in setting up the integration processes, enabling to firmly dictate conditions to the biggest players in the EU political system within the process of creating public decisions. Yet, detailed analysis of the results of the transfer of these projects to the plane of real decision-making leads to the conclusion that they do not seem to meet the expectations. Apart from Poland and, to a certain, albeit smaller degree, Hungary, none of the countries included in the aforementioned initiatives are interested in loosening the bonds with the core of the EU, which in turn is difficult to understand for Warsaw (Balcer et al., 2017, pp. 10-12).

\section{FINAL REMARKS}

For many years after 1989, Poland was regarded as a paragon of political and economic transformation. Since acquiring membership in the EU, it had basically been involved in the main trend of integration processes. The last 2 years in Poland's foreign policy towards Union structures, as well as member countries, irrefutably prove that this time is over. Currently, due to its own actions aiming for "regaining the empowerment" (Information of the Minister of Foreign Affairs..., 2016), Poland found itself on the edge of Europe in a political sense. It became almost completely alienated, the best evidence for which is the result of the voting for the President of the European Council ${ }^{16}$. Thus, one-sided exac-

16 The only candidate was a Pole - Donald Tusk - running for reelection. The voting resulted in 27 votes "for" and 1 vote "against", and surprisingly the negative one belonged to Poland. The position 
erbation of the relations with our political and commercial strategic partner, neighbor, and leader of the European project - Germany - which still remains highly calm towards Warsaw ${ }^{17}$, ought to be deemed unreasonable. In relations with another key partner - France - Poland caused itself quite some trouble, terminating, with no substantial justification, the contract for the purchase of military helicopters, which resulted in almost full freeze of bilateral relations (Balcer et al., 2017, pp. 7-8). Great Britain, on the other hand, which Poland used to perceive as a natural ally in balancing the German-French hegemony in the EU 18 , "played a trick" on Polish authorities with the decision of leaving the Union (Balcer et al., 2017, pp. 8-10). Finally, the project for establishing a strong coalition of countries from Central and Eastern Europe (the Visegrad Group), in opposition to the Berlin-Paris axis, or the broader concept of the Three Seas Initiative, turned out to have been futile. Apart from Poland and, to a certain, albeit smaller degree, Hungary, none of these countries are interested in loosening the bonds with the core of the EU, which in turn is difficult to understand for Warsaw (Balcer et al., 2017, pp. 10-12).

Apart from alienation and thus a much limited ability of establishing coalitions in key matters for Poland on the Union forum, there is a lurking thread of sanctions (e.g., taking away the right to vote in the EU Council) and massive fines (for the actions in the Białowieża Forest). In the backstage of European institutions, quite frequent are the opinions urging to partial freeze or even total shutdown of subsidies inflow to Poland (and other countries violating the rights and values of the EU) from European funds. In this last case, even though it is rather difficult to speculate whether this is likely to be implemented, due to obligations in which the parties are already engaged, it is still very much possible that receipt of such subsidies from the EU be connected with observing Union values in the perspective of the next budget (see Centre for European Reform; Politico; EUObserver). With all certainty, this would be a major blow to the pace of development of modern Poland.

One more ascertainment in final words. Bearing in mind the above, it seems that actions undertaken by the Polish government on the forum of the EU

of PiS was not supported even by the closest ally - Hungary.

17 The anti-German rhetoric was intensified, especially in statements of the politicians of the ruling camp and in communication from the public media, which is under its control. Also, the matter of war reparation payments was raised again.

18 "We will keep up dialogue and regular consultations at various levels with the most important European partners, in the first place with the United Kingdom" (Information..., 2016). 
are merely secondary to the activities witnessed inside the country. The "hard cooperation", as the authorities present it, or a "collision course", as attempted to be proved by the opposition, is utilized by the government in order to establish and consolidate social support. And it needs to be admitted that all the activity in this regard is remarkably effective, as in spite of 2 years having passed since the election, the support for PiS is maintained at a very high level (around 40\%). However, in the perspective of the image of the country and in the context of establishing its international position as a stable and predictable partner, this secondary character of the foreign policy is neither desired, nor beneficial in the long term. Unfortunately, there is no indication that this situation will change in the near future.

\section{ReFERENCES:}

Act Amending the Constitutional Tribunal Act of 22 December 2015 [Journal of Laws 2015.2217].

Action Brought on 20 July 2017 - European Commission v Republic of Poland (Case C-441/17).

Act of $30^{\text {th }}$ November 2016 on the Status of the Constitutional Tribunal Judges [Journal of Laws 2016.2073].

Act of $30^{\text {th }}$ November 2016 on the Organization and Proceedings in the Constitutional Tribunal [Journal of Laws 2016.2072].

Act of $13^{\text {th }}$ December 2016 - Regulations Introducing the Act on the Organization and Proceedings in the Constitutional Tribunal [Journal of Laws 2016.2074].

Amnesty International, International Federation for Human Rights, Human Rights Watch, Open Society European Policy Institute, Reporters without Borders (and others) (2017). Open Letter to the College of Commissioners Regarding the Situation in Poland. Brussels, February 16, 2017.

Balcer, A., Buras, P., Gromadzki, G., \& Smolar, E. (2017). In a Clinch: The European Policy of the PiS Government. Warsaw: Batory Foundation.

Charter of Fundamental Rights. OJ C 303, 14.12.2007.

Commission Recommendation of 27.07.2016 Regarding the Rule of Law in Poland, C(2016) 5703 Final, Brussels, 27.07.2016.

Commission Recommendation Regarding the Rule of Law in Poland: Questions \& Answers, MEMO/16/4479, Brussels, 21.12.2016.

Commission Recommendation of 26.07.2017 Regarding the Rule of Law in Poland Complementary to Commission Recommendations (EU) 2016/1374 and (EU) 2017/146, C(2017) 5320 Final, Brussels, 26.07.2017.

Constitutional Tribunal Act of 22 $2^{\text {nd }}$ July 2016 [Journal of Laws 2016.1157]. 
Constitutional Tribunal Judgment of 3.12.2015, Ref. No. K-34/15. Retrieved from: http://trybunal.gov.pl/en/hearings/judgments/art/8748-ustawa-o-trybunalekonstytucyjnym/.

Constitutional Tribunal Judgment of 9.12.2015, Ref. No. K-35/15. Retrieved from: http://trybunal.gov.pl/en/hearings/judgments/art/8792-nowelizacja-ustawy-otrybunale-konstytucyjnym/.

Court of Justice of the European Union (2017). Press Release No. 122/17. Luxembourg, November 20, 2017. Retrieved from: https://curia.europa.eu/jcms/upload/docs/ application/pdf/2017-11/cp170122en.pdf.

Decision of the Vice-President of the Court of Justice from 11 $11^{\text {th }}$ October 2017 (ECLI:EU:C:2017:794).

European Commission (2017). Relocation: Commission Refers the Czech Republic, Hungary and Poland to the Court of Justice. Brussels, December 7, 2017. Retrieved from: http://europa.eu/rapid/press-release_IP-17-5002_en.htm.

European Council (1993). Conclusions of the Presidency (Copenhagen, 21-22 June 1993). Retrieved from: http://www.consilium.europa.eu/media/21225/72921.pdf.

European Parliament Resolution of 13 April 2016 on the Situation in Poland (2015/3031(RSP)), P8_TA(2016)0123.

European Parliament Resolution of 15 November 2017 on the Situation of the Rule of Law and Democracy in Poland (2017/2931(RSP)), P8_TA-PROV(2017)0442.

Helsińska Fundacja Praw Człowieka [Helsinki Foundation for Human Rights] (2016). Trybunat Konstytucyjny - monitoring zmian ustawodawczych [Constitutional Tribunal Act - the Monitoring of Legislative Amendments]. Retrieved from: http:// www.hfhr.pl/trybunal-konstytucyjny-monitoring-zmian-ustawodawczych/.

Information of the Minister of Foreign Affairs on the Polish Government's Foreign Policy in 2016. January 29, 2016. Retrieved from: http://www.msz.gov.pl/resource/601901dd1db8-4a64-ba4a-9c80f2d5811b:JCR.

Ministry of Foreign Affairs Press Office (2017). MFA Statement on Poland's Response to European Commission's Complementary Recommendation of 21 December 2016. Retrieved from: http://www.msz.gov.pl/en/p/msz_en/c/MOBILE/news/mfa_statement_on_poland_s_response_to_european_commission_s_complementary_recommendation_of_21_december_2016_.

PiS boi się Komisji Weneckiej. Rząd nie zgodził się na przyjazd prawników do Polski. (2017). Newsweek Polska, 4.12.2017. Retrieved from: http://www.newsweek.pl/ polska/polityka/rzad-nie-wpusci-komisji-weneckiej-do-polski-miala-zbadacreforme-sadownictwa, artykuly,419972,1.html.

Półtorak, N. (2005). Proceduralne aspekty dochodzenia roszczeń odszkodowawczych z tytułu naruszenia prawa wspólnotowego przez państwa członkowskie. In: A. Wróbel (ed.), Stosowanie prawa Unii Europejskiej przez sądy (pp. 813-843). Kraków: Zakamycze.

Treaty of Accession. OJ L 236, 23.09.2003.

Treaty of Amsterdam. OJ C 340, 10.11.1997. 
Treaty of Lisbon. OJ C 306, 17.12.2007.

Venice Commission Opinion on Amendments to the Act of 25 June 2015 on the Constitutional Tribunal of Poland, No. 833/2015.

Venice Commission, 904/2017 - Poland - Opinion on the Judicial Reform, and: 892/2017 - Poland - Opinion on the Amended Law on the Prosecution Service. 